\title{
THE EIGHTH AMERICAN SCIENTIFIC CONGRESS
}

\author{
By Dr. Austin H. Clark
}

$\mathrm{T}^{\mathrm{H}}$ HE Eighth American Scientific Congress was held in Washington, D.C., during May 10-18, 1940. This Congress was convened by the Government of the United States with two purposes in view. The first was to advance scientific thought and achievement by enabling the scientific men and women of the twenty-one American Republics to meet each other, to exchange ideas, and to form lasting friendships. The second was to assist in the celebration of the fiftieth anniversary of the Pan American Union.

Though primarily scientific, the Congress aimed at integrating science in the Americas with the social and political life of the people, for science can no longer be considered as separate and distinct from other forms of human activity. In our modern civilization science in one form or another enters into every element of our social structure. This is particularly true in the Americas, where the origin and development of science have been democratic to an extent known nowhere else. In the Americas science knows no social classes. All groups have contributed to its advancement. There it has arisen from the people as a whole; it has been, and is being, supported by the people as a whole; and its broad aim is the betterment of the condition of the people as a whole.

Man as he used to be, as he is to-day, and as he is to be in the future ; his social organization, welfare, and activities of every kind, and especially man in his relation to America and other Americans -this was the broad subject that occupied the attention of the Eighth American Scientific Congress.

This attitude must not be mistaken for one of isolationism. For the American Republics are all keenly alive to their close affinities, individually and collectively, with the nations of the Old World. This was emphasized at the formal opening of the Congress on the evening of May 10 in a stirring and memorable address by President Franklin D. Roosevelt in which he said :

"All of the men and women of this Pan American Scientific Congress have come here to-night with heavy hearts. During the past few years we have seen event follow event, each and every one of them a shock to our hopes for the peaceful development of modern civilization. This very day three more independent nations have been cruelly invaded by force of arms.

"In some human affairs the mind of man grows accustomed to unusual actions if they are oft repeated. That is not so in the world happenings of to-day-and I am proud that it is not so. I am glad that we are shocked and angered by the tragic news from Belgium and the Netherlands and Luxembourg.

"The overwhelmingly greater part of the population of the world abhors conquest and war and blood. shed-prays that the hand of neighbour shall not be lifted against neighbour. The whole world has seen attack follow threat on so many occasions and in so many places during these later years. We have come, therefore, to the reluctant conclusion that a continuance of these processes of arms presents a definite challenge to the continuation of the type of civilization to which all of us in the three Americas have been accustomed."

In his address, President Roosevelt acknowledged with appreciation the great achievements of science in the extension and development of modern civilization. He said that the objectives toward which science is striving are closer and more peaceful relations between all nations through the spirit of co-operation and the interchange of knowledge. He deprecated the idea that science is responsible for the present "attacks on civilization which are in progress elsewhere", remarking that, "The great achievements of science and even of art can be used to destroy as well as to create ; they are only instruments'by which men try to do the things they most want to do."

The comprehensive scope of the Congress and the interdigitation of science, as commonly understood, with other forms of human activity are well brought out by the titles of the sections into which the proceedings were divided. These were: I. Anthropological Sciences (Herbert J. Spinden, chairman; Alfred V. Kidder, vice-chairman; Julian H. Steward, secretary). II. Biological Sciences (Edwin G. Conklin, chairman ; Henry A. Gleason, vice-chairman; James A. G. Rehn, secretary). III. Geological Sciences (T. Wayland Vaughan, chairman; Wendell P. Woodring, secretary). IV. Agriculture and Conservation (Hugh H. Bennett, chairman; Ernest G. Holt, secretary; J. L. Colom, assistant secretary). V. Public Health and Medicine (Thomas Parran, chairman ; Hugh S. Cumming, honorary chairman; Lewis H. Weed, vice-chairman ; A. M. Stimson, secretary; A. A. Moll, assistant secretary). VI. Physical and Chemical Sciences (Lyman J. Briggs, chairman; Eugene C. Crittenden, secretary). VII. Statistics (Stuart A. Rice, chairman; Raymond Pearl, vice-chairman ; Holbert L. Dunn, secretary; Elizabeth Phelps, executive assistant). VIII. History and Geography (C. H. Haring, 
chairman ; Preston James, vice-chairman ; Robert C. Smith, secretary; Frank Vane, assistant secretary). IX. International Law, Public Law and Jurisprudence (James Brown Scott, chairman; Herbert F. Goodrich, vice-chairman; George A. Finch, secretary; William Sanders, assistant secretary). X. Economics and Sociology (Harold G. Moulton, chairman; Benjamin Colby, secretary). XI. Education (Nicholas Murray Butler, chairman; I. L. Kandel, vice-chairman; Richard Pattee, secretary; Harold Benjamin and George I. Sánchez, rapporteurs):

Of most immediate interest to everyone are the sciences grouped under public health and medicine. These in recent years have attracted much attention throughout the Americas. In this section 119 papers were presented. Most of them were of broad general interest from the point of view of public health, though some gave details of the latest work on important and widespread ailments, or on obscure or little-known tropical diseases.

The accumulation of adequate statistical information regarding the population is recognized throughout the Americas as a matter of vital importance. In the section on statistics there were 71 papers, covering nearly all phases of the subject. These were read by statistical experts from all the twenty-one American Republics. An examination of these contributions shows how closely the conditions among the people are now being checked throughout the western hemisphere.

There were many papers on sociology and economics, these subjects being treated both from the point of view of national units and from the point of view of a closer unification of the American Republics.

A closer unification of the American Republics envisions a greater uniformity in legal systems and in legal procedure than exists at present. There were 78 papers dealing with various aspects of international law, public law and jurisprudence. Many eminent jurists took part in the discussion, including the Ministers to the United States from El Salvador and Honduras, the Mexican UnderSecretary for Foreign Affairs, and three members of the faculty of law in the University of San Marcos at Lima, Peru, the oldest university in the Americas, founded in 1551 .

There were 61 contributions in the section on education, and 64 in the section on history and geography.

Among the 42 papers in the section of agriculture and conservation, there were several of more than usual. interest. Among these were the opening address by the Hon. Henry A. Wallace, Secretary of Agriculture, on "The Vital Role of Agriculture in Inter-American Relations", and another by the Hon. Gifford Pinchot, former
Governor of Pennsylvania, on "Conservation as the Foundation of Permanent Peace". The papers as a whole covered a wide range of subjects. Soil erosion, the conservation of agricultural and forest resources, improved agricultural practices, and range problems in both South and North America received special attention.

In the section on geological sciences there were 57 papers dealing with all phases of the subject, though especially with the mineral resources.

The programme of the section of physical and chemical sciences included 62 papers, of which the most outstanding was a contribution by Prof. Albert Einstein, of the Institute for Advanced Study, Princeton University, entitled "Considerations concerning the Fundaments of Theoretical Physics" [see p. 920 of this issue].

There were 79 contributions in the section of biological sciences. Many of these were on various aspects of the extraordinarily rich fauna and flora of tropical America, though there were also many on genetics, evolution, distribution, and other topics.

The scientific programme was supplemented by an elaborate social programme which included, in addition to receptions, teas, garden-parties, and other entertainments, a visit to the famous Luray caverns of Virginia, and an inspection of the restoration of Colonial Williamsburg, Virginia, over which the "Grand Union", the predecessor of the present Union Jack, still flies.

On May 20 the delegates to the Congress were the guests of the American Philosophical Society at Philadelphia, the oldest scientific society in the United States, founded by Benjamin Franklin, and May 21 was set apart as Eighth American Scientific Congress Day at the New York World's Fair, the delegates from the Latin American Republics being the guests of the Fair throughout the day.

In the preparation and carrying out of this extensive social and scientific programme many individuals participated. Mr. Cordell Hull, Secretary of State, was honorary chairman of the Advisory Committee, of which the other cabinet officers were honorary vice-chairmen. On the organizing and advisory committees were practically all the outstanding men of science in the United States.

Those chiefly responsible for the success of the Congress were the Hon. Sumner Welles, Under-Secretary of State, president of the Congress and chairman of the Organizing Committee; Dr. Warren Kelchner, chief of the Division of International Conferences, Department of State, executive vice-president of the Congress and vice-chair. man of the Organizing Committee; Dr. Alexander Wetmore, assistant secretary of the Smithsonian Institution, secretary general of the Congress and 
secretary of the Organizing Committee; and Dr. Frank B. Jewett, president of the National Academy of Sciences, chairman of the Advisory Committee.

The Congress was adjourned with the same note of uneasiness and apprehension with which it had been opened by President Roosevelt. In his farewell address, Mr. Sumner Welles said :

"You scientists have been free to seek the truth for the sake of that truth. You have been free to use your great powers without hindrance. You have been free to publish the results of your quiet study in your laboratories, or your often hazardous observations, sometimes at the far ends of the earth, without fear that because these results might differ from accepted concepts, you, and even your families, would be subjected to the control and the oppression of the State.

"The suppression in some parts of the world to-day of the right of free inquiry, and the endeavour to control the thoughts of men, is therefore of intimate concern, not only to all scientists but likewise to all persons who believe that science has within its grasp the capacity to remedy in great part the ills of our present civilization. We cannot but speculate whether, in those parts of the world where free inquiry is no longer possible, there will not be, at least in so far as the things of the mind and the spirit are concerned, a return to the Dark Ages. What hope is there for future generations in countries where the State by fiat has declared that all persons must believe glaring distortions of the truth; where evil is declared to be good ; where falsehood is paraded as the truth ; and where aggression, pure and simple, is represented as self-defence ? . . .

"I believe-as firmly as I believe that the sun will rise once more to-morrow-that the present menace to eivilization will pass, and that the day will come when the now destructive forces of evil which men themselves have created will be vanquished. I believe that mankind will again be afforded opportunity to lay the foundations of a better world- $\mathbf{a}$ world in which freedom from fear will be established for all mankind and the right of every person to worship God, to think, to speak, to know the truth and to search for the truth will be made sure."

\title{
CONSIDERATIONS CONCERNING THE FUNDAMENTS OF THEORETICAL PHYSICS*
}

\author{
By Prof. A. Einstein, For.Mem.R.S., \\ Institute of Advanced Study, Princeton University
}

$\mathrm{W}^{\mathrm{n}}$ HAT we call physics comprises that group of natural sciences which base their concepts on measurements; and the concepts and propositions of which lend themselves to mathematical formulation. Its realm is accordingly defined as that part of the sum total of our knowledge which is capable of being expressed in mathematical terms. With the progress of science, the realm of physies has so expanded that it seems to be limited only by the limitations of the method itself. The larger part of physical research is devoted to the development of the various branches of physics, in each of which the object is the theoretical understanding of more or less restricted fields of experience, and in each of which the laws and concepts remain as closely as possible related to experience. It is this department of science with its ever-growing specialization, which has revolutionized practical life in the last centuries.

On the other hand, from the very beginning there has always been present the attempt to find a unifying theoretical basis for all these single sciences, consisting of a minimum of concepts and fundamental relationships, from which all the concepts and relationships of the single disciplines might be derived by logical process. This is what

* An address, slightly abridged, delivered at the Eighth American Scientiflc Congress at Washington on May 15. we mean by the search for a foundation of the whole of physics.

It is clear that the word foundation in this connexion does not mean something analogous in all respects to the foundations of a building. Logically considered, of course, the various single laws of physics rest upon this foundation. But whereas a building may be seriously damaged by a heavy storm or spring flood, and yet its foundations remain intact, in science the logical foundation is always in greater peril from new experiences or new knowledge than are the branch disciplines with their closer experimental contacts.

The first attempt to lay a uniform theoretical foundation in physics was the work of Newton. In his system everything is reduced to the following concepts :

(1) Mass points with invariable mass ;

(2) action at a distance between any pair of mass points ;

(3) law of motion for the mass point.

There was not, strictly speaking, any all-embracing foundation, because an explicit law was formulated only for the actions-at-a-distance of gravitation; while for other actions-at-a-distance nothing was established a priori except the law of equality of 